\title{
PENGARUH SELF-IDENTITY, SIKAP INDIVIDU DAN NORMA SUBYEKTIF TERHADAP NIAT UNTUK MEMBELI PRODUK HIJAB FASHION
}

\author{
Chandra Suparno \\ Fakultas Ekonomi dan Bisnis Universitas Jenderal Soedirman \\ Email : chandrasuparno@gmail.com
}

\begin{abstract}
Abstrak
Penelitian ini bertujuan untuk menganalisis pengaruh self-identity, sikap, dan norma subyektif individu untuk membeli produk hijab fashion. Data diambil melalui kuesioner yang disebarkan secara purposive sampling dari sebanyak 230 responden yang berasal dari kalangan mahasiswi. Hasil penelitian membuktikan bahwa self-identity memiliki pengaruh yang positif dan signifikan terhadap niat individu untuk membeli produk hijab fashion. Kemudian ditemukan juga bahwa aspek norma subyektif memiliki pengaruh yang positif signifikan terhadap niat individu untuk membeli produk hijab fashion.
\end{abstract}

Kata kunci : Hijab, Self-identity, Sikap, Norma subyektif

\section{Abstract}

This research attempted to analysis the impact of self-identity, consumers attitude, and subjective norm towards intention to buy hijab fashion product. The data were gathered by using self-adminitrated questionaire to 230 respondents which came from higher education student girls. The result revealed that self-identity has a positive and significant impact towards intention to buy hijab fashion. Furthermore, it also found that subjective norm affected the aspect of individual intention to buy hijab fashion significantly as well.

Keywords : Hijab, Self-identity, Attitude, Subjective norm 


\section{PENDAHULUAN}

\section{Latar Belakang Masalah}

Perkembangan hijab fashion saat ini telah menjadi perhatian khusus dalam sektor industri pakaian, khususnya di negara muslim. Seiring dengan meningkatnya jumlah pemeluk Islam di seluruh dunia, tingkat konsumsi terhadap produk halal dan jasa berbasis syariat Islam, termasuk di dalamnya industri fashion, juga semakin tinggi di seluruh dunia (Siti hasnah hassan \& Harmimi harun, 2016).

Perempuan Muslim saat ini memiliki kesadaran yang lebih terhadap citra dan identitas sosialnya, dan kesadaran tersebut mempengaruhi pola konsumsi mereka, salah satunya dalam hal pola konsumsi fashion. Masih terbatasnya keberadaan busana muslim yang fashionable menjadi salah satu masalah yang dihadapi oleh mereka (Potts, 2009) sehingga biasanya mereka mengambil referensi dari produk fashion barat. Kondisi demikian terbukti dari banyaknya praktik pengislamisasian model fashion yang dilakukan oleh segmen konsumen remaja (Wilson, 2012).

Meski demikian, menurut Ghani (2011), entitas perempuan muslim saat ini telah memiliki banyak pilihan dalam hal gaya dan cara berpakaian yang ditandai pula dengan banyaknya kemunculan media fashion muslim, blog, para perancang busana muslim, dan ritel-ritel yang menjual pakaian muslim. Bahkan, menurut Potts (2009), mayoritas negara muslim saat ini telah memberikan banyak keleluasaan kepada kalangan perempuan untuk mengekspresikan kepribadiannya melalui cara berbusana dengan berbagai macam gaya dan aksesoris di dalamnya. Wilson (2015), menyimpulkan bahwa tren hijab fashion akan terus berkembang di seluruh dunia.

Perkembangan hijab fashion saat ini sudah semakin pesat, bahkan telah menjadi salah satu dari arus utama fashion yang ada di dunia. Meski demikian, literatur dan penelitian mengenai hijab fashion masih sangat sedikit sehingga perlu untuk dilakukan penelitian lebih lanjut (Siti hasnah hassan \& Harmimi harun, 2016; Gökariksel \& Secor, 2010). Berdasarkan uraian latar belakang tersebut, penelitian ini akan membahas mengenai pengaruh hubungan antara self-identity, sikap, dan norma subyektif terhadap niat untuk membeli produk hijab fashion.

\section{HIPOTESIS DAN MODEL PENELITIAN}

\section{Definisi dan perkembangan hijab fashion} Hijab merupakan salah satu kewajiban yang diperintahkan kepada perempuan muslim. Arti kata hijab diambil dari bahasa arab yang artinya untuk menutup (El Guindi, 1999). Konsep hijab fashion merujuk kepada tren perkembangan hijab sebagai wujud dari ekspresi individu yang pada praktiknya terinspirasi dari perkembangan tren fashion terbaru, dimana dalam praktiknya, para pemakai hijab fashion ini menerapkan berbagai macam kustomisasi dan personalisasi terhadap gaya hijab yang mereka kenakan (Siti hasnah hassan \& Harmimi harun, 2016 ). Berbeda dengan hijab pada umumnya yang hanya berupa kerudung dan pakaian longgar, penampilan hijab fashion lebih menyesuaikan diri dengan arus fashion terbaru.

\section{Konsep Self-identity}

Konsep self-identity didefinisikan sebagai sebuah penilaian terintegrasi seorang individu terhadap citra dirinya sendiri sebagai seseorang yang unik, yang membedakan dirinya dengan orang lain (Bernstein da et al, 1994). Selain itu, secara etimologi, identitas dalam pengertian ini hanya berkaitan dengan identitas personal seorang individu, bukan pengalamannya (Joseph a bailey, 2003).

Saat ini, konsumen tidak hanya memperhatikan aspek fungsional pada saat membeli sebuah produk tetapi juga karena personal statement yang ingin ditampilkan melalui produk yang mereka gunakan (Siti hasnah hassan \& Harmimi harun, 2016). 
Sebagaimana yang disebutkan oleh Grubb and Grathwohl (1967), bahwa pemeblian semacam ini disebut dengan symbloic consumption atau konsumesi simbolis, yang dalam hal ini konsumen hanya menggunakan produk sebagai alat untuk menciptakan, membangun dan menjaga identitas mereka.

\section{Konsep Sikap}

Menurut Beck dan Ajzen (1991), sikap merupakan sebuah evaluasi yang dilakukan oleh individu mengenai tingkatan tentang seberapa baik atau tidak evaluasi seseorang tersebut terhadap sesuatu. Lebih lanjut, sikap dapat diartikan juga sebagai sebuah reaksi atau respon seseorang yang masih tertutup terhadap suatu stimulus atau obyek (Soekidjo N, 2003).

\section{Konsep Norma Subyektif}

Konsep norma subjektif didefinisikan oleh Ajzen dan Fishbein (1980) sebagai sebuah penilaian pribadi setiap individu sebagai sebuah reaksi dari tekanan lingkungan untuk melakukan atau tidak melakukan suatu perilaku tertentu.

\section{Hubungan antara self-identity dan niat}

Konsep self-identity dipandang sebagai salah satu faktor penting dalam menentukan sikap dan perilaku seseorang (Biddle, Bank, \& Slavings, 1987). Bahkan Joanne $r$ smith et al (2008) menyatakan bahwa terdapat korelasi yang positif antara self-identity dengan perilaku seseorang. Berdasarkan uraian tersebut, hipotesis pada penelitian ini adalah.
Hipotesis 1 : self-identity berpengaruh positif terhadap niat individu untuk membeli produk hijab fashion.

\section{Hubungan antara sikap, norma subjektif dan niat}

Akar konsep hubungan antara sikap, norma subjektif dengan niat terdapat dalam theory of reasoned action. Tujuan utama dari teori ini adalah untuk memprediksi niat dan tujuan seseorang untuk melakukan suatu tindakan yang dilandasi oleh dua faktor utama, yaitu faktor personal atausikap, dan faktor lingkungan sosial atau norma subyektif (Lada et al., 2009). Adapun konteks niat dalam penelitian ini adalah niat untuk membeli produk hijab fashion. Teori ini telah banyak digunakan sebagai pendekatan untuk memahami niat pembelian konsumen dalam berbagai jenis produk, seperti makanan organik, online shopping, dan niat untuk membeli produk halal (Battacherjee, 2000; George, 2002; Jarvenpaa and Todd, 1997; Kalafatis et al.,1999; Lada et al.,2009;Sparks and Shepherd, 1992).

Berdasarkan uraian tersebut, penulis merumuskan hipotesis sebagai berikut.

Hipotesis 2 : Sikap berpengaruh positif terhadap niat untuk membeli produk hijab fashion

Hipotesis 3 : Norma subyektif berpengaruh positif terhadap niat untuk membeli produk hijab fashion.

Model kerangka pemikiran teoritis dapat dijelaskan pada Gambar 1.

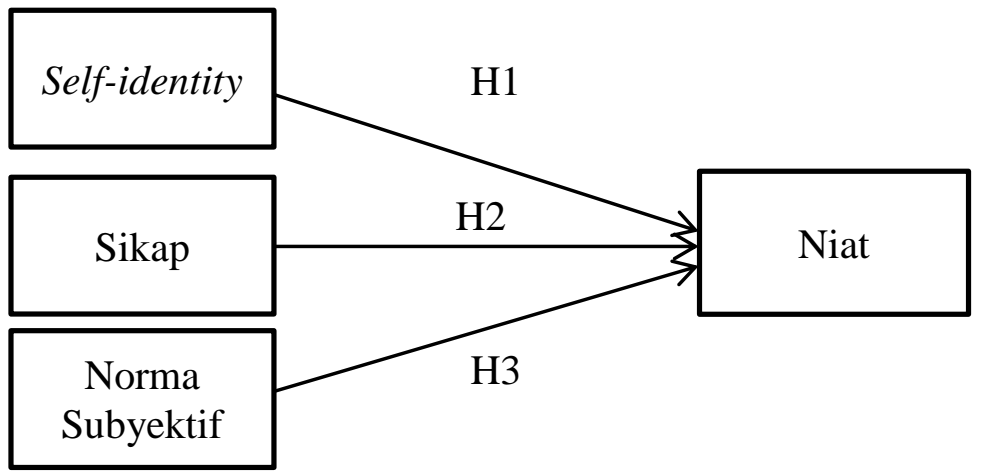

Gambar 1. Model Kerangka Pemikiran Teoritis

Sumber: dikembangkan untuk penelitian (2017) 


\section{METODE PENELITIAN}

Populasi dalam penelitian ini adalah mahasiswi yang mengenakan hijab di Universitas Jenderal Soedirman. Jumlah sampel untuk penelitian adalah 230 . Pengumpulan sampel penelitian menggunakan metode purposive sampling. Penelitian ini menggunakan metode survey, dengan kuesioner sebagai instrumen untuk mengumpulkan data. Pengukuran variabel menggunakan skala Likert dengan rentang pilihan: Sangat Tidak Setuju (STS) sampai dengan Sangat Setuju (SS) sebanyak 5 kemungkinan jawaban. Kuesioner untuk variabel self-identity diadaptasi dari Joanne $r$ smith et al (2008) sedangkan untuk variabel sikap dan norma subyektif dimodifikasi dari Beck dan Ajzen (1991), dengan item pertanyaan sebagai yang disajikan pada Tabel 1.

Hipotesis dalam penelitian ini diuji menggunakan analisis regresi berganda dengan menggunakan software SPSS seri 16.

Tabel 1. Indikator kuesioner penelitian

\begin{tabular}{|c|c|c|}
\hline No & Variabel & Item pertanyaan \\
\hline 1 & Self-identity & $\begin{array}{l}\text { 1. Saya mempertimbangkan diri saya sebagai } \\
\text { contoh tipikal pembeli produk hijab fashion } \\
\text { yang saya sukai. } \\
\text { 2. Saya melihat diri saya sebagai contoh tipikal } \\
\text { pembeli produk hijab fashion yang saya } \\
\text { sukai. }\end{array}$ \\
\hline 2 & Sikap & $\begin{array}{l}\text { 1. Bagi saya, memakai hijab fashion itu sangat } \\
\text { penting } \\
\text { 2. Bagi saya, memakai hijab fashion itu lebih } \\
\text { bermanfaat. } \\
\text { 3. Bagi saya, memakai hijab fashion itu lebih } \\
\text { bagus daripada tidak memakai hijab }\end{array}$ \\
\hline 3 & Norma Subjektif & $\begin{array}{l}\text { 1. Orang-orang yang dekat dan penting bagi } \\
\text { saya banyak yang memakai hijab fashion } \\
\text { 2. Orang lain dapat mempengaruhi saya untuk } \\
\text { memakai hijab fashion } \\
\text { 3. Keluarga saya menyukai hijab fashion } \\
\text { 4. Keluarga saya menyuruh saya untuk } \\
\text { memakai hijab fashion } \\
\text { 5. Teman-teman saya lebih menyarankan saya } \\
\text { untuk memakai hijab fashion }\end{array}$ \\
\hline 4 & Niat membeli & $\begin{array}{l}\text { 1. Saya berniat untuk hanya membeli dan } \\
\text { mengenakan hijab fashion dalam waktu dekat } \\
\text { 2. Saya akan membeli hijab fashion dalam } \\
\text { waktu dekat } \\
\text { 3. Saya memiliki rencana untuk membeli hijab } \\
\text { fashion dalam waktu dekat }\end{array}$ \\
\hline
\end{tabular}




\section{HASIL DAN PEMBAHASAN \\ Uji Reliabilitas}

Berdasarkan hasil uji reliabilitas yang disajikan pada Tabel 2, diketahui nilai Alpa Cronbach sebesar 0,749. Hal tersebut menunjukkan bahwa semua item dari variabel dalam penelitian ini memenuhi unsur reliabilitas dengan nilai Alpha Cronbach $(\alpha)$ lebih besar dari 0,60 (Ghozali, 2006).

\section{Tabel 2. Uji Reliabilitas}

\begin{tabular}{rrr}
\hline Cronbach's Alpha & N of Items & \\
\hline .749 & & 13 \\
\hline
\end{tabular}

\section{Uji Normalitas}

Dilakukan dengan statistik kolmogorov-Smirnov terhadap Unstandardized residual hasil regresi. Hasil uji asumsi normalitas dapat dilihat pada Tabel 3. Dari hasil uji normalitas pada Tabel 3, diketahui bahwa nilai probabilitas (sig) KolmogorovSmirnov $(0,987)$ lebih besar dari alpha $(0,05)$ sehingga dapat disimpulkan bahwa data residual regresi terdistribusi normal.

\section{Uji Multikolinieritas}

Model regresi yang baik adalah yang tidak terjadi korelasi di antara variabel independennya. Cara yang digunakan untuk mendeteksi multikolinieritas melalui tolerance value dan VIF (Variance Inflasion Factor). Jika Tolerance value $>0,1$ dan VIF $\leq 10$ maka tidak terjadi multikolinieritas (Ghozali,2006). Hasil uji asumsi multikolinieritas dapat dilihat pada Tabel 4.

Berdasarkan hasil pengujian, disimpulkan bahwa di dalam model regresi penelitian ini tidak terdapat gejala multikolinieritas karena semua nilai tolerance $>0,1$ dan nilai VIF $\leq 10$.

\section{Pengujian Kelayakan Model}

Pengujian model penelitian menggunakan koefisien determinasi disesuaikan (R2) yang disajikan pada Tabel 6 , dan uji $\mathrm{F}$ terlihat pada Tabel 7. Tabel 6 memperlihatkan nilai adjusted $\mathrm{R}^{2}$ sebesar 0,198 yang berarti 19,8\% dari model penelitian ini dijelaskan oleh variabel yang diteliti, yaitu variabel self-identity,sikap, dan norma subyektif sedangkan sisanya dijelaskan oleh variabel yang lain di luar model penelitian. Metode ini belum mampu menggambarkan uji kelayakan model dengan baik dikarenakan sangat bergantung pada banyaknya variabel bebas (Ghozali,2006), sehingga semakin banyak variabel bebas, maka semakin tinggi $\mathrm{R}^{2}$, begitu pula sebaliknya. Oleh sebab itu, pengujian keandalan model dilanjutkan dengan menggukanan uji $\mathrm{F}$ seperti terlihat Tabel 7 . Dari hasil uji F pada Tabel 7 dapat diketahui bahwa F hitung sebesar 11,568 dengan probabilitas 0,000 . Nilai probabilitas jauh lebih kecil dari 0,05, maka model regresi dalam penelitian ini disimpulkan fit. Demikian pula jika membandingkan $F$ hitung dengan $\mathrm{F}$ Tabel. Kesimpulan $\mathrm{F}$ Tabel $(2,644)$ lebih kecil dari $\mathrm{F}$ hitung $(11,568)$.

\section{Uji Hipotesis}

Semua hasil uji hipotesis ke dua disajikan dalam Tabel 5 sampai dengan Tabel 7.

\section{Uji Hipotesis 1}

Berdasarkan hasil analisis pada Tabel 5 dapat dijelaskan bahwa koefisien regesi pengaruh variabel self-identity terhadap variabel niat adalah positif sebesar 0,395 dengan nilai probabilitas signifikansi sebesar 0,00 lebih kecil dari 0,05 sehingga hipotesis pertama yang diajukan hasilnya diterima, yaitu bahwa self-identity berpengaruh positif dan signifikan terhadap niat untuk membeli produk hijab fashion.

\section{Uji Hipotesis 2}

Berdasarkan hasil analisis pada Tabel 5 dapat dijelaskan bahwa koefisien regesi pengaruh variabel sikap terhadap variabel niat adalah negatif sebesar 0,149 dengan nilai probabilitas signifikansi sebesar 0,024 lebih kecil dari 0,05 sehingga hipotesis ke dua yang diajukan hasilnya diterima, oleh karena itu dapat disimpulkan bahwa variabel sikap berpengaruh positif dan signifikan terhadap niat untuk membeli produk hijab fashion. 


\section{Uji Hipotesis 3}

Berdasarkan hasil analisis pada Tabel 5 dapat dijelaskan bahwa koefisien regesi pengaruh variabel norma subyektif terhadap variabel niat adalah positif sebesar 0,162 dengan nilai probabilitas signifikansi sebesar 0,001 lebih kecil dari 0,05 sehingga hipotesis ke tiga yang diajukan hasilnya diterima, oleh karena itu dapat disimpulkan bahwa variabel norma subjektif berpengaruh positif dan signifikan terhadap niat untuk membeli produk hijab fashion.

\section{PENUTUP}

\section{Simpulan}

Simpulan dari hasil penelitian ini adalah bahwa aspek self-identity berpengaruh positif dan signifikan terhadap niat individu untuk membeli hijab fashion. Kemudian, diketahui juga bahwa aspek sikap dan norma subyektif berpengaruh positif dan signifikan terhadap niat individu untuk membeli produk hijab fashion. Temuan tersebut memperkuat penelitian sebelumnya dari (Biddle, Bank, \& Slavings, 1987) dan Joanne $r$ smith et al (2008). Selain itu, model dalam penelitian ini masih belum cukup komprehensif dalam menjelaskan aspek niat individu untuk memilih produk hijab fashion, sehingga perlu adanya penelitian lanjutan dengan menambahkan variabel-variabel lain guna menyempurnakan model penelitian sebelumnya.

\section{Implikasi Manajerial}

Berdasarkan hasil penelitian, terdapat poin penting yang dapat diambil oleh para praktisi di bidang pemasaran produk hijab fashion. Hal tersebut adalah bahwa para pemasar di bidang produk hijab harus memperhatikan aspek identitas dari para konsumen hijab fashion. Aspek identitas disini diartikan sebagai bagaimana seorang individu mengidentifikasi dan mengasosiasikan dirinya dengan jenis hijab fashion tertentu. Hal ini penting karena aspek identitas memiliki pengaruh positif terhadap niat para konsumen memilih produk hijab fashion. Selain itu, faktor lain yang perlu diperhatikan adalah aspek sikap dan lingkungan sosial atau komunitas karena kedua aspek ini pun memiliki pengaruh yang cukup kuat terhadap pembentukan perilaku seseorang, maka dari itu para pelaku bisnis hijab fashion harus mampu menjalin kedekatan dan bahkan kerjasama dengan komunitas-komunitas pemakai hijab fashion yang pada akhirnya diharapkan dapat memberikan pengaruh dan sugesti-sugesti positif kepada setiap anggotanya sehingga dapat memengaruhi anggotanya yang lain untuk semakin meningkatkan intensi untuk membeli produk hijab fashion.

Tabel 3. Hasil uji normalitas

One-Sample Kolmogorov-Smirnov Test

\begin{tabular}{llr}
\hline & & Unstandardized Residual \\
\hline $\mathrm{N}$ & & 230 \\
Normal Parameters $^{\mathrm{a}}$ & Mean & .0000000 \\
& Std. Deviation & 2.06562824 \\
Most Extreme & Absolute & .030 \\
Differences & Positive & .027 \\
& Negative & -.030 \\
Kolmogorov-Smirnov Z & .450 \\
Asymp. Sig. (2-tailed) & & .987 \\
\hline
\end{tabular}

a. Test distribution is Normal. 
Tabel 4. Hasil uji multikolinieritas

\begin{tabular}{llrr}
\hline & & \multicolumn{2}{c}{ Collinearity Statistics } \\
\cline { 3 - 4 } Model & & Tolerance & VIF \\
\hline 1 & (Constant) & & \\
& Self_identity & .966 & 1.035 \\
& Sikap & .941 & 1.062 \\
& Norma_Subyektif & .939 & 1.065 \\
\hline
\end{tabular}

Tabel 5. Hasil uji hipotesis

Coefficients $^{\mathbf{a}}$

\begin{tabular}{|c|c|c|c|c|c|c|}
\hline \multirow{2}{*}{\multicolumn{2}{|c|}{ Model }} & \multicolumn{2}{|c|}{$\begin{array}{c}\text { Unstandardized } \\
\text { Coefficients }\end{array}$} & \multirow{2}{*}{$\begin{array}{c}\begin{array}{c}\text { Standardized } \\
\text { Coefficients }\end{array} \\
\text { Beta }\end{array}$} & \multirow[b]{2}{*}{$\mathrm{t}$} & \multirow[b]{2}{*}{ Sig. } \\
\hline & & B & Std. Error & & & \\
\hline \multirow[t]{4}{*}{1} & (Constant) & 6.590 & 2.051 & & 3.212 & .002 \\
\hline & Self_identity & .394 & .095 & .263 & 4.160 & .000 \\
\hline & Sikap & .149 & .038 & .224 & 3.634 & .024 \\
\hline & Norma_Subyektif & .162 & .050 & .209 & 3.245 & .001 \\
\hline
\end{tabular}

a. Dependent Variable: Niat_membeli

Tabel 6. Hasil uji koefisien determinasi

Model Summary

\begin{tabular}{llrrr}
\hline Model & R & R Square & Adjusted R Square & Std. Error of the Estimate \\
\hline 1 & $.467^{\text {a }}$ & .218 & .198 & 1.755 \\
\hline
\end{tabular}

a. Predictors: (Constant), Norma_Subyektif, Self_identity, Sikap

Tabel 7. Hasil uji F

ANOVA $^{b}$

\begin{tabular}{llrrrrr}
\hline Model & Sum of Squares & df & Mean Square & F & \multicolumn{1}{c}{ Sig. } \\
\hline 1 & Regression & 150.046 & 3 & 50.015 & 11.568 & $.000^{\mathrm{a}}$ \\
& Residual & 977.102 & 226 & 4.323 & & \\
& Total & 1127.148 & 229 & & & \\
\hline
\end{tabular}

a. Predictors: (Constant), Norma_Subyektif, Self_identity, Sikap

b. Dependent Variable: Niat_membeli 


\section{DAFTAR PUSTAKA}

Ajzen, I., dan Fishbein, M. (1980). Understanding Attitudes and Predicting Social Behavior. Upper Saddle River, NJ, USA: Prentice-Hall, Inc.

Battacherjee, A. (2000), "Acceptance of ecommerce services: the case of electronic brokerages", IEEE Transactions on Systems, Man, and Cybernetics - Part A: Systems and Humans,

Vol. 30 No. 4, pp. 411-20.

Beck, L., \& Ajzen, I. (1991). Predicting dishonest actions using the theory of planned behavior. Journal of Research in Personality (25), 285-301.

Bernstein da et al. (1994). Psychology $3^{\text {rd }}$ ed. Princeton, New Jersey: Houghton Mifflin Co.

Biddle, B. J., Bank, B. J., \& Slavings, R. L. (1987). Norms, preferences, identities and retention decisions. Social Psychology Quarterly, 50, 322-337.

El Guindi, F. (1999). Veil: Modesty, Privacy and Resistance. New York: Berg.

Kalafatis, S., Pollard, M., East, R. and Tsogas, M.H. (1999), "Green marketing and Ajzen theory of planned behaviour: a cross-market examination", Journal ofConsumer Marketing, Vol. 16

No. 5, pp. 441-60.

Lada, S., Tanakinjal, G.H. and Amin, H. (2009), "Predicting intention to choose Halal products using theory of reasoned action", International Journal of Islamic and Middle Eastern Finance and Management, Vol. 2 No. 1, pp. 66-76.
Potts, J. (2009). Lifting the Veil on Fashion Filling The Gaps Between Modesty and Fashion Apparels. The Ohio State University.

Siti Hasnah Hassan Harmimi Harun,(2016),"Factors influencing fashion consciousness in hijab fashion consumption among hijabistas", Journal of Islamic Marketing, Vol. 7 Iss 4.

Soekidjo,Notoatmodjo.2005. Metodologi

Penelitian Kesehatan. Jakarta: Rineka Cipta.

Sparks, P. and Shepherd, R. (1992), "Selfidentity and the theory of planned behavior: assessing

the role of identification with 'green consumerism"”, Social Psychology Quarterly, Vol. 55 No. 4, pp. 388-99.

Wilson, J. A. (2012). Muslim Youth Culture: A New Wave of Hip Hop Grunge. Halal Journal, 32-38.

(2015). Ramadan Reflections. The Marketeers, 115-11

George, J.F. (2002), "Influences on the intent to make internet purchases", Internet Research, Vol. 12 No. 2, pp. 165-80.

Ghozali, I. (2006). Model Persamaan Struktural: Konsep dam Aplikasi dengan Program Amos Versi 5. Semarang: BP Universitas Diponegoro. 